\title{
Recruiting Young Love: How Christians Talk about Homosexuality, by Mark D. Jordan
}

Chicago: University of Chicago Press, 20II | xx +273 pages | ISBN: 978-0-226-41044-9 (hardback) \$35.00

This very fine book follows the author's highly regarded work, The Invention of Sodom in Christian Theology (Chicago: University of Chicago Press, 1997), which explored the creation of the category of "sodomy," placing homosexual acts at the very extreme end of sinfulness. This is a similarly careful book, which works from a wide variety of published and unpublished sources to explore the changing language which the churches have used about homosexual acts. It is another case of a very fine publication by University of Chicago Press in this field.

The range is broader than the title might suggest. Ten very solid chapters begin with a fine chapter on the first exploration of adolescence by $\mathrm{G}$. Stanley Hall in 1904 and then extend back to the development of a language of homosexuality linked to Krafft-Ebeling and Havelock Ellis. The second chapter on "First Reports of Hidden Worlds" takes up a second contextual factor: the work of Kinsey from his first report in 1948 and responses by various people including Reinhold Niebuhr and Gore Vidal. Chapter 3 looks at the early considerations by mainline Protestant churches, and the notable writing by Sherwin Bailey. I found it fascinating to see the context of Bailey's pioneering work. While the purpose of this book is not to construct a narrative, one is implicit within the search for the developing language of Christians about sexuality, and this was particularly interesting in making sense of the early writing on Christianity and homosexuality.

Chapter 4 traces the emergence of "homophiles," church people seeking to reconcile homosexuality with Christianity. None of these authors is major, but each is contextualised with care. Chapter 5 begins with the British Quaker report, the first to propose that there should be no barriers to full participation by homosexual people in the life of the churches and discussions in America. In chapter 6, the mythology of the Stonewall riots is superbly critiqued, and this chapter has at its core a study of Troy Perry, the founder of the Metropolitan Community Churches. As Jordan argues, Troy Perry is every bit as significant as the secular Stonewall riot and earlier as well. The 
chapter also looks at John T. McNeill the notable Catholic liberation writer. In chapter 7 we turn back to the conservatives and the fear of children, with a most interesting account of the rhetoric of Anita Bryant. This really is the book at its best. Chapter 8 traces the emergence of Exodus, and various other anti-gay organisations. Then in chapter 9, Jordan looks at the way the AIDS epidemic changed the rhetoric and led to the outrageous statements of Jerry Falwell that this was God's particular judgement on homosexuals. The debate in the I980s grew more bitter and polemical. The final chapter looks at the voices of young people and for young people. The conclusion is on "How Not to Talk about Sex in Church."

This is a fine set of studies and is suggestive of the history of homosexuality and the churches. In none of these cases, however, is the actual history traced; the focus is rather on the changing rhetoric surrounding homosexuality, and so what is traced is a series of broad cultural shifts. This is a very significant approach, for it enables us to understand that in the I960s the medicalised understanding of the "invert" predisposed observers to cast it as a medical or psychological issue, if not as a moral evil. Later shifts of language mean that campaigners like Anita Bryant and Jerry Falwell steadily amended their language to make it a moral choice, and began to make distinctions between orientation and practice, which could not have been conceived when it was viewed as a sickness. All this casts light on the current marriage debate for example, although the author does not particularly address it. In effect if homosexuality just "is" as a way of being and relating, then refusing it recognition is that much more difficult. At the same time, in effect in this history nothing actually happens except the change of language use, as is the current fashion, leaving history without any particular agents, and theology with just an analytical task. Yet this is the very best of the current style of histories of language, because sexuality is in essence a concept, and the changing categorisation of it is particularly important, and although the author analyses changing language use, his deft analysis gives us careful indications of events beyond the changing linguistic patterns. Moreover this is an exceptionally crafted book, written with passion, clarity and a high tone of thoughtful rhetoric. I recommend it with enthusiasm.

One little interesting note. The author draws attention to a book, Christianity and Sex Problems by Hugh Northcote, whom he describes as an Anglican vicar from New Zealand. I was intrigued by this vicar of Lincoln who corresponded with Havelock Ellis and found that he went on to serve as an Anglican chaplain in France before retiring to Christchurch. His 1906 book 
comes on top of two books on women's equality and on Prohibition. His Sex book was published in America and several times reprinted there. Only one copy is held in New Zealand, but many of his examples are drawn from this country. It is an interesting example of the ways in which changing values are reflected in this country.

Peter Lineham

Massey University 